\title{
BE SWIFT, MY DARLING
}

\author{
There's no escaping fate.
}

\section{BY JOHN MORAN}

$\mathrm{W}$ hen you wake and start reading this, head fuddled by the cold sleep that crosses the stars, then you're in what the Kree call the saddle (don't worry who the Kree are, my lover, I'll get to that shortly).

For now, just realize that the ring beside you opens an airlock. You'll need to wear the suit because the first two metres are vacuum, but when you jump the gap, and operate the far side by pulling what looks like a purple orchid, you'll find yourself in the alien spacecraft I discovered on my shift three weeks ago (without waking you my darling, I'm sorry).

You'll find this hard, as you enter the glass-smooth tunnel and follow its crimson undulations into the darkness, but you'll also remember this note and tell yourself, as you have all your life, that there's no such thing as fate. You're wrong, my dear, but until the end you won't believe me.

At the end of the tunnel you'll find a tall insect of bilateral symmetry and upright gait, its chest etched with orange glyphs and its screech itching your skin like nails on metal even as one arm turns what appears to be a piece of bamboo in your direction. The shot will miss you, my darling, but shock will drop you to one knee before you reply with the gun on your suit.

This is a Kree, and when you stand again and cross its dying body, your breath will catch as you remember this note.

There are two tunnels. (You think you won't, but you will) take the left-hand one and creep into a red oval that pulsates like a heartbeat. Containers lie here, and some of the Kree survey equipment, but there's no point being wantonly destructive. Just shudder at the way they lie like melted flesh from a Dalí, then make your way through the middle to the heart of the hive.

The Kree are older than us, my darling, and their technology is organic, but through your helmet you won't smell the pheromones keeping the nest viable, or hear the million-pulse beat that shivers from the queen. Instead you'll rush through hanging veils of flesh to a distant glow, amazed that a ship with hundreds of corridors should be so empty, until you remember that I've arranged the timing exactly to give you free access.

You'll panic, then, when you remember what lies in wait, and want to turn back, but you're brave, my darling, so you'll bite your lip and continue even though you'll need the suit's medication to stop you throwing up.

\footnotetext{
(1)
}

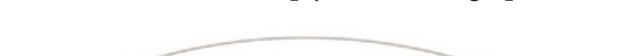
added the life of a dozen worlds to the mix. Before you, will be a root from Satir-4, a lizard from Rigus and two clams from the oceans of Ligellan. You'll imagine the traces of what they once were, and shudder at the idea that creatures can know the Kree from the inside even as they are known. At this point you'll remember your mission and run once more, past half-molten creatures still wailing into the thin air, past fish failing to swim through organic glue, to an open space waiting for more samples. And in the last mound you'll find me.

Don't judge me harshly, darling, as you raise your gun to my pleading eyes, for the Kree give as well as take. From them I've learned that time is organic, growing immovable branches of reality from nodes of choice.

That chittering you'll hear as you aim is just part of my proof. I'm connected to the Kree now, and I've done the mathematics so many times I know that there was no way to bring you in and let you out safely.

Instead, a saddle point. Shoot us both, or let the Kree bind us together in a transformation stranger than you can imagine. I know you expect to put me out of my misery, but here at the end I can only say that you'll have to decide for yourself.

Just begin. Put on the suit and enter the airlock. Be swift, my darling. I'm waiting. -

John Moran has been a chemical analyst, nuclear physicist and art-shop owner. He currently works as a security consultant for a UK bank. 